\title{
Have Recent Financial Reforms Improved Financial Accountability in the Australian Commonwealth Public Sector?
}

\author{
Graham Bowrey ${ }^{\dagger}$, \\ School of Accounting and Finance \\ University of Wollongong
}

\begin{abstract}
Since the early 1990s the Australian Commonwealth public sector has undergone significant financial reforms, due primarily to the current federal Liberal government's drive to improve the financial accountability of the Commonwealth Government. These reforms include the adoption of accrual accounting and budgeting and the development and implementation of an outcomes and outputs framework. These reforms culminated in the first full federal budget to be developed on an accrual basis in $1999-2000$. This paper will examine the implementation of these reforms and the associated processes to determine whether or not the Commonwealth government is more financially transparent and better able to discharge its financial accountability. It is argued the complexity of the processes associated with, and the reporting requirements of these reforms may have actually decreased the level of accountability to the key party to whom accountability is due - the Australian public.
\end{abstract}

Key words: financial reform, financial accountability, accrual accounting, outcomes and outputs framework

${ }^{\dagger}$ The author would like to thank the two anonymous reviewers for their comments and suggestions. All errors contained in this paper are solely the responsibility of the author.

\section{INTRODUCTION}

The Australian Commonwealth public service has undergone significant financial and nonfinancial reforms over the past two decades in an effort to improve its efficiency, effectiveness and accountability (Guthrie 1998, p. 2; Barton 2005, p. 138), its transparency (Barrett 1994, p. 2), as well as its productivity and competitiveness (Boxall 1998, p. 18). The two main objectives of the financial reforms identified by the previous Secretary of the Commonwealth Department of Finance and Administration (DOFA), Dr Boxall, is the encouragement of a culture of performance and making the public sector more responsive to the needs of government (1998, p. 18). These objectives are reflected in DOFA's statement that the financial reforms were implemented to place greater focus on "measuring what is being produced, what is being achieved and what is the full cost of individual goods and services, and on the reporting of performance" (1999, p. 2). The most noted financial reforms have been the adoption of accrual accounting and budgeting and the development and implementation of an outcomes and output framework

These reforms resulted in the first full federal budget to be developed on an accrual basis in 1999-2000. The outcomes and outputs framework, by which government appropriations are specifically directed to government organisations, was developed in parallel with the first full whole of government accrual budget. It is important to note that along with the adoption of 
accrual accounting and budgeting and the implementation of an outcomes and outputs framework the federal government also introduced specific legislation to support its reform agenda. This legislation included the Financial Management and Accountability (FMA) Act 1997 and the Commonwealth Authorities and Companies (CAC) Act 1997, which provide for the use of Commonwealth resources, as well the reporting and accountability rules for Commonwealth organisations, the Charter of Budget Honesty Act 1998, which provides a framework for the conduct of Government fiscal policy, and the Auditor-General Act 1997 which provides a broad reaching mandate for the Auditor-General and the Australian National Audit Office (Barrett 2004, p. 7).

The Senate, also known as the House of Review is one of the main mechanisms used by the government and parliament to discharge their financial accountabilities. The Australian Constitution, section 81, outlines that "all revenues or moneys raised or received by the Executive Government of the Commonwealth shall form one Consolidated Revenue Fund, to be appropriated for the purposes of the Commonwealth". The Senate, through various legislative committees, scrutinises the planned government organisations' estimates of required funds [budget estimates], contained in specific appropriation bills, which are created as per section 83 of the Australian Constitution "no money shall be drawn from the Treasury [Consolidated Revenue Fund] of the Commonwealth except under appropriation made by law". These annual appropriation bills, secure money for the implementation and delivery of services of the government and the parliament for the financial year (Evans, 2004). Appropriation Bills No. 1 and 3 provide funding for the "ordinary annual services" of Government (DOFA 2006a) and while Appropriation Bills No. 2 and 4 provide funding for capital injections as well as administered funding for government outcomes. The government organisation is expected to use the funds obtained from its accrual appropriation(s) "to manage all its finances, including capital replacement and working capital requirements" (National Commission of Audit (NCOA), Chapter 9).

To assist senators, who participate in the legislative committees, as well as other members of parliament to understand the various appropriation bills, each government portfolio produces a portfolio budget statement (PBS). These PBSs are designed to "inform Senators, Members and the public of the proposed allocation of resources to Government outcomes. The PBS provides an important means by which the Executive Government remains accountable to the Parliament" (DOFA, 2006a) as well provide an agenda for the senate legislative hearings.

The primary purpose of this paper is to explore the adoption of accrual accounting and budgeting and the implementation of the outcomes and outputs framework in the Australian Commonwealth public sector and examine whether these financial reforms have the meet the current federal Liberal government's objectives in fostering greater financial transparency, and in turn, better government financial accountability - both to parliament and to the Australian public. The methodology, the way in which research is conducted (Dillard 1991, p. 12), for this paper is based on a subjectivist position which can be referred to as ideographic research (Dillard 1991, p. 12; Gaffikin 2006, p. 8). This type of research relies on qualitative methods including archival research and hermeneutics which were the key methods used in collecting and analysing the data for this paper. 


\section{Financial Reform}

The Commonwealth public sector has experienced over the last decade some significant reforms, particularly in relation to financial management and taxation. The reasons behind the financial reforms are subject to conjecture; however, several commentators identify the "new managerialism" in the public sector (Jackson and Lapsley, 2003, p. 360) and the perceived need of the public sector to improve productivity and competitiveness in response to increased globalisation (Boxall, 1998) as primary reasons. For example, Dr Boxall (1998), the then Secretary of the Department of Finance and Administration, identified the introduction of accrual-based budgeting, the increased use of market-based and financial management tools and the preparation of accrual-based whole-of-government financial statements as some of the key reasons of public sector financial reform.

The significant public sector financial reforms did not occur in an ad hoc manner; rather, they were specifically developed with two objectives. The first, which complements Jackson and Lapsley's (2003) notion of "new managerialism”, is to promote a culture of performance (Hoque and Moll, 2001; Boxall, 1998). The second identified objective was to increase public sector organisations' accountability, efficiency and effectiveness, to make them more responsive to the needs of government (Hoque and Moll, 2001; Boxall, 1998). This new culture of performance was also in response to meeting the increased accountability expectations of government and the Australian electorate.

The next section discusses one of the key financial reforms, in the Commonwealth public sector, the adoption of accrual budgeting and accounting.

\section{Accrual Accounting}

The private sector has been using accrual accounting over the past 200 years, and one of the reasons for it continued use is that it has been able to meet the changing information needs of businesses (Barton, 1999, p. 31). Accrual accounting involves the recognition of revenues and expenses when they are incurred, rather than when cash is received or paid. Fellew and Kelaher (1991) explain that accrual accounting is based on the concept of matching costs to income. In its 1996 report, the National Commission of Audit (NCOA) stated that accrual budgets would match the flows of economic benefits over particular periods to the flows of economic costs. In doing so they would incorporate information on expenses accruing and revenues arising from current policies (NCOA, Chapter 9).

Before accrual accounting was implemented in the Commonwealth public sector, accounting and budgeting was based on a cash basis. This involves recording actual and budgeted cash inflows and outflows (Hoque and Moll, 2001, p. 319), that is, revenues and expenses are recognised when cash is received or paid. This is consistent with the previous method of funding government organisations, where they received cash to fund programs and activities. However, under accrual budgeting, government organisations receive operating and capital funds to produce specified outputs and outcomes (Boxall, 1998). The Management Advisory Board (MAB) explains that one of the main aims of the Commonwealth public sector in adopting accrual accounting was met by allocating costs and benefits to the reporting period to which they relate, as well as defining the resources controlled by an organisation at the end of that period (1997). The NCAO suggested that 
... accrual accounting would eliminate the distortions in the cash based budget deficit or surplus caused by asset sales and repayments of advances. ... it [accrual budgeting] would also include asset depreciation and accruing employee costs such as superannuation in the measure. This would make the resulting budget result (deficit/surplus) more transparent than the existing (unadjusted) cash based result (Chapter 9)

Another benefit of accrual accounting is that government and its organisations can minimise costs, because accrual accounting provides a cost base with which to cost products and service delivery accurately (Webster, 1998; Hoque and Moll, 2001). DOFA also identifies this benefit, explaining that "accrual budgeting substantially expands the range of information available for the effective management of public finances” (DOFA, 1999, p. 8).

Accrual accounting can be seen promoting better financial accountability as it allows users of reported financial information to make reliable financial and performance comparisons between reporting periods and between public and private sector organisations. The MAB (1997) suggests that accrual information can be used to develop standard ratio analyses, whereby simple, understandable measures can be monitored and compared within the organisation and with other organisations: "ratios allow a simple snapshot of key financial performance measures" (MAB, 1997, p. 63).

While the implementation of accrual accounting has brought several benefits, it has also created concern and confusion for some, including public servants working in both finance and non-finance roles. The change has had a significant operational impact, and accordingly, the mindset of the government organisation officer has had to change significantly. Public sector managers were now required to focus on outputs and outcomes, rather than on inputs. They had to, and continue to, ask themselves what accrual accounting means, why they must measure, record and seek funding for non-cash items such as depreciation, and how this might improve the delivery of services to the Australian public. This situation is exacerbated by many public servants who still operate on a "cash mentality", whereby they focus on the funds they have to use in a period of time rather than on using the funds for a specific output. This confusion is further compounded by the policy that requires unused appropriations be returned to consolidated revenue at the end of the financial year, and before the government organisation can access to these unused funds, they need to apply formally to DOFA.

\section{Outcomes and Outputs}

As discussed above the move to accrual accounting was part of a package of financial reforms the Commonwealth undertook to accommodate the desired paradigm shift to a greater focus on measuring what is and is to be achieved, determining the full cost of goods and services, and on performance reporting (DOFA, 1999, p. 2). The other key reform, introduced in parallel with accrual accounting, was the development and implementation of an outcomes and outputs framework. While the previous accounting method, cash accounting, focused on inputs and the control of expenditure (Hoque and Moll, 2001), accrual accounting focuses on outcomes and outputs.

The Management Advisory Board (MAB) explains that an outcome is the impact desired from the implementation of government policy. For example, Outcome 1 of the Department of Families, Community Services and Indigenous Affairs Portfolio (FaCSIA) is "Greater selfreliance and economic, social and community engagement for Indigenous Australians" (2007a). The government assigns funds to government organisations based on specific outcome statements 
as the "outcome statements perform a specific legal function by describing the purposes of appropriated funds" (MAB, 1997, p. 15). Thus outcome statements serve two specific purposes: they define the impacts government expects, and "articulate the purpose of the relevant appropriations under the Appropriation Acts of the Commonwealth Budget" (DOFA, 2000, p. 10). However the outcomes are quite ambiguous and are very difficult to measure. This presents a paradox in that the government implemented an outcomes and outputs framework for greater focus on "measuring what is being produced, what is being achieved and what is the full cost of individual goods and services, and on the reporting of performance" (DOFA 1999, p. 2) yet how do you accurately measure greater self reliance and economic, social and community engagement for Indigenous Australians? The answer is partly addressed through the identification of specific outputs which are defined as the "tangible presence of the agency amongst its clients, customers and stakeholders" (DOFA 2000, p. 19). For example, an output linked to the FaCSIA outcome of "greater self reliance ... for Indigenous Australians" is Administration of Native Title and Land Rights (FaSCIA, 2007b). The performance of FaCSIA in relation to this output is measured by both qualitative and quantitative performance measures. The qualitative performance measure is "Effective support to Indigenous land claimants and title holders" and quantitative measure is "Professional native title services delivered in native title representative areas and effective management of Commonwealth land rights legislation" (FaSCIA, 2007b). Unlike outcomes, outputs are not part of the legislative requirements for appropriation bills; however, they are often the key focus of committee members during the estimates hearings.

Based on accrual budgeting and the outcomes and outputs framework government organisations prepare budget estimates which are used to determine the amount government funds the organisation requires to achieve the government determined outcomes. The next section will discuss the basic process of how the government funds are provided to government organisations..

\section{Appropriation Bills}

DOFA (2006b) explains that Appropriation bills are the bills that "appropriate money from the Consolidated Revenue Fund to provide funds for government and parliamentary expenditure". The creation of these bills is inline with the requirements outlined under section 83 of the Australian Constitution which states that funds can only be drawn from the Consolidated Revenue Fund under an appropriation made by law (Commonwealth of Australia Constitution Act). Appropriation bills are introduced into the House of Representatives by the Treasurer (on budget night in May each year), and are then tabled in the Senate. Two of the key functions of the Senate are to review legislative (including appropriation bills) and other proposals initiated in the House of Representatives and "to provide adequate scrutiny of financial measures, especially by committees considering estimates" (Evans, 2004). The committees that review the appropriations are called Senate legislation committees.

The following diagram outlines the basic flow from government organisations developing internal strategic plans to achieve the government agreed outcomes to the receipt of funds to implement the tasks and activities on the strategic plans. 


\section{Diagram 1}

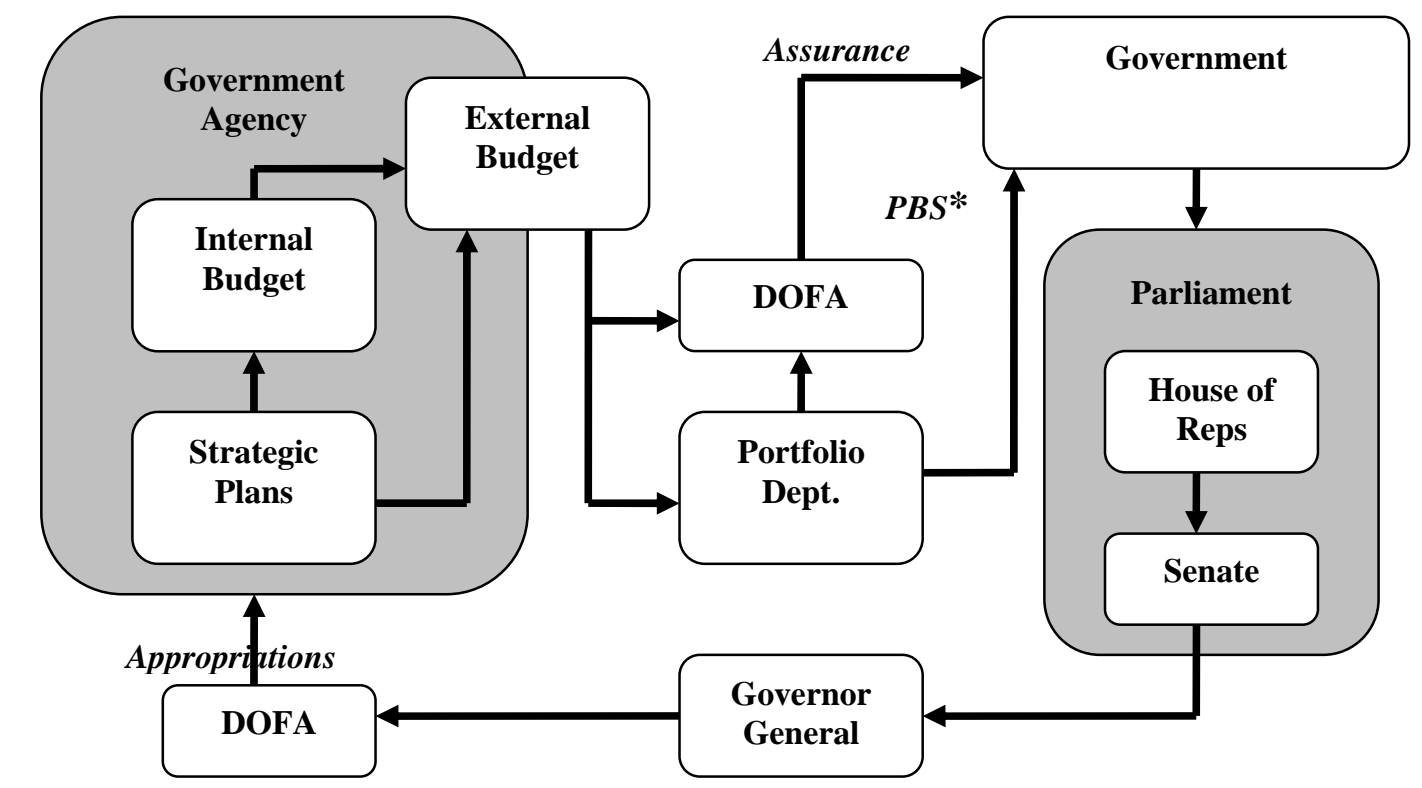

* PBS - Portfolio Budget Statements

The next section will provide a brief outline of the structure and role, in relation to reviewing various government agencies budget estimates, of the Senate legislation committees.

\section{Senate Legislation Committees}

Twice each year the Senate refers the estimates of the proposed annual expenditure of government departments and authorities, contained in the appropriation bills, to one of its legislation committees for their examination and reporting. These committees consist of six senators - three from the government (one of whom is the committee chair), two from the opposition and one representing the minority parties or independents (Senate Brief 5). However it is also quite normal for other senators to attend the hearing and indeed participate in the hearing. Yet their participation during the hearings is limited, for example they cannot participate in specific functions of the committee such as voting on points of order raised during the hearing. Harry Evans (2004), then Clerk of the Senate, describes how the legislation committees' scrutiny of the estimates in appropriation bills allows the Senate to assess the performance of the public service and its administration of government policy and programs. One of the interesting points of these estimates hearings is that one of the rules of the committee, standing order 26, explains the committee must take all evidence in public. Indeed not only is it possible for members of the public to sit-in on the committee hearings, it is also possible to watch the proceeding live on the Parliament of Australia's website and obtain complete transcripts, Hansard, of the meeting via the same website. This level of access to the committees can be seen as a component of discharging the accountabilities of the government and parliament through an apparent high level of transparency. 
Evans also explains that another key feature of the committee is that senators can directly question officers of the public service about a government organisation's proposed expenditure and the effectiveness and efficiency of various programs. However, public servants are not meant to comment on government policy. Indeed, at the beginning of each committee hearing the chair states: "The Senate has resolved that an officer of a department of the Commonwealth or of a state shall not be asked to give opinions on matters of policy" (Finance and Public Administration Legislation Committee, 2006). For example, they should not answer a question about whether an immigration detention policy is the correct measure to address problems identified with illegal immigrants. This directive by the chair does not preclude the senators asking (or baiting) officers; so, to assist the committee, the relevant government minister (or their representative) is present during the committee hearings. This often leads to the tone of the hearing moving from an enquiry into the proposed expenditure of public funds to a political brawl between senators from opposing sides of politics. This is particularly evident when a committee member, or participating senator, is the alternative Minister (ie opposition member) and uses the opportunity to directly challenge the current Minister on matters of policy. These discussions can detract from the objective of and dominate the legislation committee.

Another important process occurs when a public servant is unable to supply an immediate answer to a question asked by a member of the committee or is unsure of the correct answer. As outlined in Senate Brief 5 Consideration of Estimates by the Senate's Legislation Committees the question is then taken 'on notice', which gives the government organisation a specific period to obtain and provide a written answer to the committee. The following is an extract from the 2006 estimates hearing of the Environment, Communications, Information Technology and the Arts Legislation Committee Estimates.

\begin{abstract}
Senator (Non-government) - I have a few questions. There is a reference in the environmental budget overview statement at paragraph 6 . The minister's foreword states:

Our international focus is also reflected in the Government's environment aid budget, which now reaches $\$ 316$ million ... Can the officers provide me with a breakdown of that \$316 million.
\end{abstract}

Senior Public Servant —We would have to take that detail on notice. We receive those figures from AusAID.

Senator (Non-government) - I am surprised, given it is in the minister's statement, that you are not aware of how it is going to be spent.

Senior Public Servant - We certainly have the information. I am just checking through my papers as to whether I have actually brought it with me. But it will certainly be in the department.

Senator (Non-government)—I would hope so.

Senior Public Servant - It is not in the papers that I have brought with me, but we can certainly take it on notice. We have the information in the department.

A problem with questions taken on notice is that the information is provided back to the senator via the committee is not included in the readily available Hansard transcripts. There appears to be a tendency to take more difficult questions on notice which in turn reduces the level of transparency of the committee hearing. Indeed some senators will provide government organisations with lists of questions on notice without the questions even being asked during the 
committee. This level of silence reduces the transparency of the process and reduces the effectiveness of the committee.

The function of the senate legislation committee whilst improving the level of transparency and inturn being a tool for discharging government and parliament accountability is not seen as the best process but rather as the current process. For example ALP Senator Kim Carr an experienced government and opposition senator made the following comment about the effectiveness of estimates committees:

I have over the years spent much time in Senate Estimates hearings, which I enjoy greatly. But I don't believe that basic facts about the way the Commonwealth dollar is being spent, should have to be winkled out via this process (Carr, 2003, p. 10).

Senate Brief 10 states that "This process [senate estimates hearings] provides a vehicle for those committees to examine the performance of departments". It also allows senators - especially non-government senators - to gather information on the operations of government (Senate Brief 5). To assist the committee members have several sources from which to draw information to scrutinise the estimates and to formulate questions for the government organisation's officers. These include portfolio budget statements (PBS), portfolio additional estimates statements (PAES), annual reports of agencies, the reports of the auditor-general, corporate plans and other budget statements (Evans, 2004; Senate Brief 5). While this level of information appears it would be very useful for reviewing a government organisation's budget estimates it worth considering the background, education and employment, of the senators on these committees. Do the senators, particularly the committee members, have sufficient knowledge and experience to know what they are actually trying to examine? While the process may be a useful tool in assisting the parliament discharging the accountability of the government are the actors involved in the process know what they are reviewing? This concern is particularly significant at this point in time given that as at the $30^{\text {th }}$ June 2007 of the 52 senators who currently sit on these committees only three have formal accounting qualifications and these three are all government senators.

The following section discusses the primary source of information for senators during the legislation committees, the portfolio budget statements (PBS), which contains the budget estimates of each government organisation for each government policy measure.

\section{Portfolio Budget Statements (PBS)}

Each portfolio department is required to prepare a portfolio budget statement, in conjunction with the Departments of Finance and Administration, Treasury and Prime Minister and Cabinet, which should explain the government-agreed outcomes of government organisations and the proposed allocation of appropriations. The DOFA guidelines for the PBS outline that the purpose of the PBS is to explain appropriation bills (numbers 1 and 2) to senators and members.

Stephen Bartos, former Deputy Secretary of the DOFA, told the Finance and Public Administration Legislation Committee in 1999 that the PBS:

...is one of the central budget documents that enables effective public scrutiny of Commonwealth expenditures. As such, it needs to be in a format that is tailored to the information needs of senators and members to ensure that it is able to be used as a document that can enhance accountability and ensure disclosure (17 June 1999, p. 2). 
Some senators and members (especially those not qualified or experienced in interpreting financial reports), find the PBS a confusing document particularly as it only provides information on the estimates of the current year's performance, the next financial year's budget (the focus of the document) and forward estimates for the next three years. Another problem found by users of the PBS is that it only provides information by outputs and outcomes rather than by division of a portfolio. The following extract from the 2007 estimates hearing of the Environment, Communications, Information Technology and the Arts Legislation Committee Estimates is an example where the PBS is seen as a tool that does not provide sufficient information for examining and reviewing a government organisation's budget estimates and actually hinders transparency.

Senator (Non-government) —Why is it then that the Office of the Supervising Scientist [OSS] is expected to present an annual report to parliament and its annual reporting requirements are not part of the department of environment's requirements? If they are special enough to provide a discrete annual report, why do they not even get one mention in your PBS?

Senior public servant-They do get a mention in our annual report, but it is just like I mentioned before: the PBS does not look at the issues division by division. The treatment of the Office of the Supervising Scientist is no different than any other area. You will see the list by outputs and outcomes and not on a divisional basis. That is the way the Commonwealth reports in the portfolio budget statement.

Senator (Non-government) - This is about the third year in a row. What I am getting at is there is no transparency as to exactly what you are allocating in the financial year to the OSS.

Senior public servant - I am sure Mr XXXX will answer questions about his financial position, but the PBS is prepared completely in accordance with advice that we get in terms of its preparation. If you flip through it, you will not find mention on a division-by-division basis other than their contribution to the outcomes and outputs. I know that does not help you, but-

Senator (Non-government) - I will just make the point that the OSS is significant and important enough to table its own discrete annual report to the parliament but does not even get one mention in your PBS.

"In approving the budget estimates for the coming year, senators realistically want to be reassured that the past year's spending was proper and actually achieved something. They do not have that reassurance in the current PBS" (DOFA, 2000, p. 26). The tabling of annual reports (albeit usually some months after the estimates hearings) provides this historical data to allow senators and members to make comparisons between the funds appropriated and the funds spent. In the above example, the senator would be able a access the relevant information in the Office of the Supervising Scientist's annual report, however the annual report is not due to be tabled in parliament until October, some five months after the legislation committee has met to review and report on the budget appropriations. So it is reasonable assume senators would use the previous financial year's annual report to assist in examining the current year's budget estimates. The use of these dated reports again raises the issue on whether transparency can be adequately met and whether financial accountability is appropriately discharged. 


\section{Financial Accountability}

Funnell and Cooper summarise accountability as the obligation to answer for decisions made and actions conducted on authority which has been transferred from another (1998, p. 30). The senate legislation committee is a key feature in the government's and parliament's desire to properly discharge their financial accountabilities to the Australia electorate. The senate legislation committee provides a channel for government organisations, through senior public servants and their respective Ministers, to be held to account for the decisions they have made in relation to the use of the funds appropriated. A key criterion for the discharge of financial accountability is transparency. Cameron (2004) succinctly describes transparency as the essence of accountability. In the public sector, legislation committees examining estimates have no power to take evidence in secret; that is, they are public hearings. This is one way that transparency is achieved in the public sector. In addition, all documents that are received officially as evidence by the committees become public documents accessible to all, as are the transcripts of the proceedings. This level of transparency is generally supported by members of these committees. For example Senator Kim Carr (ALP Senator) explained there is a need to "maintain full public accountability and to ensure that it is not diminished by notions of 'commercial confidentiality”' (2003, p. 8). However, this comment raises the issue of an interesting paradox. The public sector through the adoption of various private sector practices and procedures such as accrual accounting could be considered to have a need to protect information that would in the private sector be considered commercial-in-confidence. Indeed some times Ministers and public servants try to justify non compliance to a request for information during a senate estimates hearings as being due to commercial in confidence. For example the following is an extract from the 2006 estimates hearing of the Environment, Communications, Information Technology and the Arts Legislation Committee Estimates:

Senior Public Servant-I am not actually allowed to provide daily running cost for the Aurora Australis under our charter, but the general range of costs-

Senator (Non-government) — That is under the charter with P\&O, is it?

Senior Public Servant - Yes. The general range of costs-

Senator (Non-government)—Why is that?

Senior Public Servant — It is a commercial-in-confidence arrangement.

Senator (Non-government)—Why?

Senior Public Servant - It has been that way for many years.

Senator (Non-government)—Yes, but why is it? It is public money that is being expended there, isn't it?

Senior Public Servant - It is commercial in confidence.

Senator (Non-government) — Why is it commercial in confidence? It is a straight arrangement with a shipping company.

Government Minister-We put it up for tender on a regular basis, so there is commercial stress on them. They would want to keep that-but you know what the total running costs of the program are, so it is in terms of parliamentary accountability. 
The Australasian Accounting Business \& Finance Journal, August, 2007

Bowrey: Recent Financial Reforms Public Sector. Vol. 1, No. 3.

Senator (Non-government)—Extraordinary.

However at the beginning of each estimates hearing the Chair of the committee reads out the prescribed directions for the hearing which includes:

\begin{abstract}
The Senate, by resolution in 1999, endorsed the following test of relevance of questions at estimates hearings. It reads: Any questions going to the operations or financial positions of the departments and agencies which are seeking funds in the estimates are relevant questions for the purpose of estimates hearings.

I remind officers that the Senate has resolved that there are no areas in connection with the expenditure of public funds where any person has discretion to withhold details or explanations from the parliament or its committees, unless the parliament has expressly provided otherwise.
\end{abstract}

Unfortunately the Chair of the committee is also a member of the government so like the example provided above questions outside the scope of the committee often go through relatively unchecked unless a non-government senator pursues the matter.

Accountability is a complex notion and it is not one which can be adequately addressed through one definition, however it is generally accepted, as found in Funnell and Cooper's summary, that accountability implies a relationship of authority, based on the idea that those who are accountable are in some sense subordinate to those to whom they must give account (Mulgan, 1997, p. 27). However, it is questionable whether parliament and government are subordinate to the Australian electorate, especially because parliament developed and approved the implementation of the current accountability processes - "in the public sector, the public accountability process is largely determined by legislation and the parliamentary system" (Cameron, 2004, p. 59). Pat Barrett (2003), a former auditor-general, explained that accountability in the public sector implies conformity with a system of administrative processes designed to designate authority for administrative actions, and simultaneously provide a framework for reporting and checking on actions taken.

The concerns relating to the public accountability process being determined largely by those who are accountable is increased by the conflicting interests of the committee members. Loney (2004) outlines how government members of the committees are firstly members of a political party, and are expected to be loyal to their party, and secondly members of legislative committees. Similarly, the committee members are also in a position to use the committee to promote themselves and their party. This could explain some behaviour that does not directly contribute to discharging accountability, for example, aggressive questioning of government policy during an estimates hearing.

Despite these concerns, the level of documented and reported performance information is fundamental to improve public sector accountability (Cameron, 2004), and this view is shared by several actors in the public sector. For example, Senator Kim Carr (2003) explained that the reporting obligations of government organisations are fundamental parts of public service accountability. The Department of Finance and Administration also significantly focuses on ensuring that government organisations properly and fully meet their reporting obligations. The Australian National Audit Office (ANAO) similarly contributes to the discharging of public sector financial accountability through its auditing of government organisations and by tabling their reports in parliament (Barrett, 2003). This responsibility of the ANAO is outlined under 
section 57 of the Financial Management and Accountability Act 1997 and section 35 of the Commonwealth Authorities and Companies Act 1997,

The senate legislation committee is a key feature in the government's and parliament's desire to ensure their financial accountabilities are, or at least seen to be, discharged. The following diagram provides a simplified example of the processes.

\section{Diagram 2}

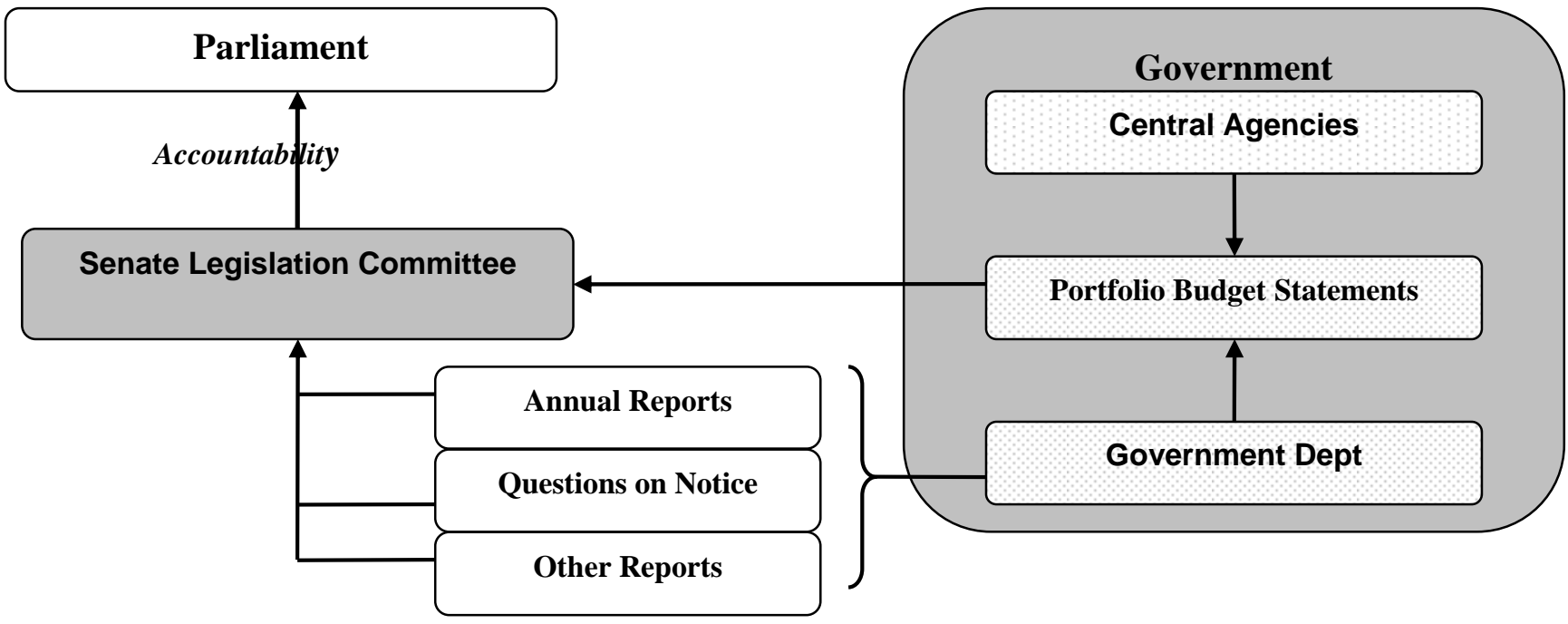

The question remains have the recent financial reforms improved financial accountability and have the other objectives of these recent reforms been met?

\section{CONCLUSION}

The recent financial reforms, accrual accounting and the outcomes and outputs framework, instigated several operational and contextual changes for the public sector. Their reporting obligations have since increased significantly, as has the scope of their reports. For example, under the cash accounting system, there is no facility to identify, measure and report on expenses such as depreciation which leads to distorted budget deficits or surpluses. However, under accrual accounting, depreciation expenses are included as is accumulated depreciation, a contra asset, which impacts on the book value of the relevant asset and therefore needs to be considered in the development of government organisations’ budget appropriations.

These financial reforms may seem superficially to have improved financial accountability within the Commonwealth public sector. The objectives of the financial reforms, including to promote a culture of performance (Hoque and Moll, 2001; Boxall, 1998) and increase public sector organisations' accountability, efficiency and effectiveness (Hoque and Moll, 2001; Boxall, 1998) are unlikely to have resulted in anything other than better accountability. However, the complexity of the new processes, reporting requirements and various "discharging" mechanisms may have actually decreased the level of accountability. The PBS does not provide any 
information on the past performance of a government organisation and the information that is contained in the PBS is based specifically on outcomes and outputs, which are generally very ambiguous. The government does require the government organisations to prepare and table an annual report which would provide more useful, and clearer, information however the timing of when this report is tabled in parliament, October, means the value of the document to the main estimates process is significantly diminished. It can also be argued the new processes don't provide adequate transparency, which is the essence of accountability (Cameron, 2004). This lack of transparency can be explained due to the number of questions during the estimates hearing being taken 'on-notice' and the ambiguous nature of the objectives of government organisations, outcomes.

\section{Limitations of this study and future research}

The main limitation of this research is the level of review undertaken on the various components of the financial, reporting and accountability processes. There is a wealth of data to collect on each component and it is possible that significant studies could be undertaken on these components individually. For example it would be worthwhile studying whether the PBS is more informative than the previous information sources available to senators during the estimates committee process. This could be undertaken by reviewing the Hansard transcripts from previous estimates hearings as well as developing questionnaires for senators and other members of parliament who have experienced the pre and post periods of the recent financial reforms. Another area of future research could be a study on specific government departments' behaviours towards implementing and working with the financial reforms. It would also be possible to conduct some empirical research on whether accrual accounting has led to more or less under or overspends, in comparison to budget estimates tabled in parliament. As the lack of specific literature indicates there are significant researching opportunities in this area.

\section{REFERENCES}

Barrett, P.J., Australian Auditor-General, 2003, “Government sector accountability — the impact of service charters in the Australian public sector", Queensland Commonwealth Regional Heads Forum, $15^{\text {th }}$ Annual Government Business Conference, May.

Barton, A., 1999, "Public and Private Sector Accounting - The non-identical twins", Australian Accounting Review, Vol. 9, No. 2, pp. 22-31.

Barton, A., 2005, Professional Accounting Standards and the Public Sector - a Mismatch, Abacus, Vol. 41, No. 2, pp. $138-158$

Boxall. P., 1998, “The revolution in government accounting”, Australian CPA, Vol. 68, No. 3, pp. $18-20$.

Cameron, W., 2004, "Public accountability: Effectiveness, equity, ethics", Australian Journal of Public Administration, Vol. 63, No. 4, pp. 59-67.

Carr, K. 2003, “Achieving the Right Balance between Responsiveness, Transparency and Accountability in Policy Advice and Implementation, Australian Journal of Public Administration, Vol. 63, No. 3, pp. 3-11.

Commonwealth of Australia, 2006, Official Committee Hansard, Senate, Environment, Communications, Information Technology and The Arts Legislation Committee Estimates, Budget Estimates Thursday, 25 May 2006

Commonwealth of Australia Constitution Act, Chapter 4 Finance and Trade, at http://www.aph.gov.au/senate/general/constitution/chapter4.htm (accessed 14 July 2007) 
Department of Family, Community Services and Indigenous Affairs (FaCSIA) (2007a) Portfolio Overview at http://www.facsia.gov.au/internet/facsinternet.nsf/VIA/budget200708/\$File/2007-2008_FaCSIA_PBS_03_overview.pdf (accessed 14 July 2007)

Department of Family, Community Services and Indigenous Affairs (FaCSIA) (2007b) Agency Budget Statements at http://www.facsia.gov.au/internet/facsinternet.nsf/VIA/budget200708/\$File/2007-2008_FaCSIA_PBS_04_facsia.pdf (accessed 14 July 2007)

Department of Finance and Administration (DOFA), 2006, Appropriation Bills, at http://www.finance.gov.au/budgetgroup/appropriation_bills.html (accessed 16 February 2007)

Department of Finance and Administration (DOFA), 1999, Review of Budget Estimates Production Arrangements, July 1999.

Department of Finance and Administration (DOFA), 2000, The Outcomes \& Outputs Framework: Guidance Document, November 2000.

Department of Finance and Administration (DOFA), 2002, Estimates Memorandum — 2002-13.

Department of Finance and Administration (DOFA), 2006a at http://www.finance.gov.au/budgetgroup/Other_Guidance_Notes/portfolio_budget_statemen ts_p.html (accessed 14 July 2007)

Department of Finance and Administration (DOFA), 2006b at http://www.finance.gov.au/budgetgroup/appropriation_bills.html (accessed 14 July 2007)

Dillard, J.F. 1991, Accounting as a Critical Social Science, Accounting, auditing and Accountability Journal, Vol. 4, No. 1, pp. 8 - 28

Evans, H., 2004, Odgers' Australian Senate Practice, 11th edition, Canberra, Department of the Senate, 2004, at: http://www.aph.gov.au/senate/pubs/odgers/index.htm (accessed 16 June 2006).

Fellew, K. and Kelaher, M., 1991, Managing Government the Corporate Way, Australian Accountant, Vol. 61, No. 3. pp. 20-22.

Finance and Public Administration Legislation Committee, (17 June 1999).

Finance and Public Administration Legislation Committee, (24 May 2006).

Funnell, W.N. and Cooper. K., 1998, Public Sector Accounting and Accountability in Australia, University of New South Wales Press Ltd, Sydney

Gaffikin, M. 2006 The Critique of Accounting Theory, University of Wollongong, School of Accounting and Finance Working Paper Series 06/25

Guthrie, J., 1998 Application of accrual accounting in the Australian Public Sector - Rhetoric or Reality?, Financial Accountability and Management, Vol. 14, No. 1, pp. 1 - 19

Hoque, Z. and Moll. J., 2001, "Public Sector Reform: Implications for accounting, accountability and performance of state-owned entities - an Australian perspective", The International Journal of Public Sector Management, Vol. 14, No. 4, pp. 304-326.

Jackson, A. and Lapsley, I., 2003, “The diffusion of accounting practices in the new 'managerial' public sector, International Journal of Operations and Production Management, Vol. 16, No. 5, pp. 359-372.

Loney P., 2004, “Beware the Gap! Parliamentary Oversight or Parliament Overlooked?” A paper for the Association of Public Accounts Committees Conference, Nelspruit, South Africa, October 2004.

Management Advisory Board (MAB), 1997, Beyond bean counting: Effective Financial Management in the APS - 1998 and Beyond, December 1997.

Mulgan, R., 1997, "The Process of Public Accountability", Australian Journal of Public Administration, Vol. 56, No.1, pp. 25-36. 
National Commission of Audit (NCOA), Report to the Commonwealth Government, AGPS, Canberra, June 1996 at http://www.finance.gov.au/pubs/ncoa/chap9.htm (accessed 14 July 2007)

Senate Brief No. 10, The Role of the Senate, February 2005, at: http://www.aph.gov.au/Senate/pubs/briefs/brief10.htm (accessed 16 June 2007).

Senate Brief No. 5, Consideration of Estimates by the Senate's Legislation Committees, February 2005, at: http://www.aph.gov.au/Senate/pubs/briefs/brief05.htm (accessed 16 June 2007).

Webster, A., 1998, "Improving performance: Accrual accounting points the way ahead", Australian CPA, Vol. 68, No. 3, pp. 24-26. 